
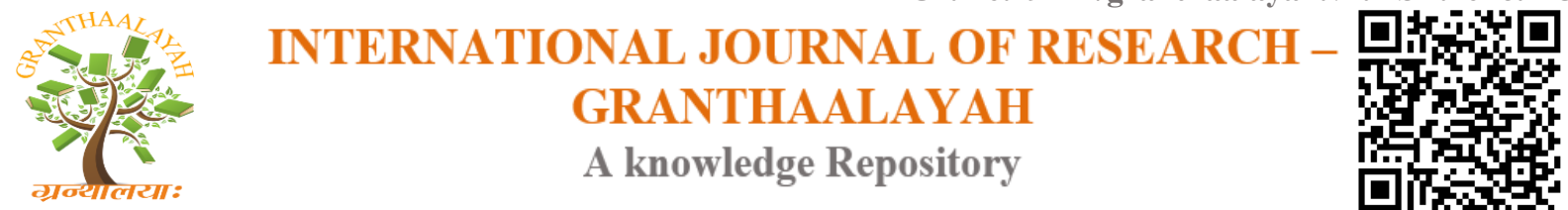

Management

\title{
A STUDY ON INVESTMENT IN GOLD AMONG WORKING PEOPLE IN PALAYAMKOTTAI
}

\author{
A. kamila Fathima ${ }^{* 1}$, Dr. A.Hamil ${ }^{2}$ \\ ${ }^{* 1}$ M.Phil., Sadakathullah Appa College, Palayamkottai, INDIA \\ ${ }^{2}$ Associate Professor of Commerce and Dean of Arts, Sadakathullah Appa College, Tirunelveli, \\ INDIA
}

\begin{abstract}
Gold is a metal which has a cultural as well traditional value in avail multi options of investment. In this article, I have focused on investment in gold among working people and try to find out working people's view towards investment in gold. I took both primary as well as secondary data for this article.

Keywords:

Culture of gold, Investment behavior in gold.

Cite This Article: A. kamila Fathima, and Dr. A.Hamil, "A STUDY ON INVESTMENT IN GOLD AMONG WORKING PEOPLE IN PALAYAMKOTTAI" International Journal of Research - Granthaalayah, Vol. 4, No. 4: SE (2016): 14-20.
\end{abstract}

\section{INTRODUCTION}

Investment in financial view is buying or making an asset with certain expectation of earning of rents, interest, dividend or some combination of these returns. Such as investment in gold, building, land, shares, debentures, fixed deposits etc., in this article focus only on investment in gold. Gold is one among precious metal known by humans for centuries. It is valued in global currency. So people give more important to gold. In this article I have used primary and secondary data. I have collected data from working people in Palayamkottai.

\section{CULTURAL VALUE}

Gold has wide connection in Indian culture. Indians love affair with gold is timeless spanning over centuries. In every occasion is closely related with gold. It is a heirloom of the family. Gold is given as a gift from grandparents when baby born. In marriage bride getting ornaments as a gift from the parents, even bridegroom is getting it form in laws. It is a status symbol in this country. People ready to flaunt their ornaments in festivals. They used to buy gold almost all ceremony. Akshayathrithy is a special occasion to buy gold with the belief in hoard of gold. 
Gold has a religious connection. Devotees give gold as a tribute to God in temples after fulfilling their rogation.

\section{ADVANTAGES OF INVESTMENT IN GOLD}

- Investment in gold has low risk then compare with shares and debenture.

- Gold, platinum, silver is a universal currency

- Gold is a status symbol. So people do investment in gold with any hesitation.

- It is a liquid assert so people can use it in their financial crisis.

\section{DISADVANTAGE}

- Gold has a low resale value. When jewels are taken to resale, it has taken to lesser value then market price.

- High making charge is camouflage in purchasing ornaments. All consumers don't have bargaining ability.

- Keeping of gold at home is a apprehension. Criminal activities are raising for gold.

- No tax deduction for purchasing gold.

- Investing in gold doesn't give any regular income like debenture from share, rent from building, interest from fixed deposits etc.,

\section{OBJECTIVES}

- To study on working people attitude towards investment in gold at Palayamkottai city.

- To study the investment priority and what influencing the customer to invest in gold.

- To find out the relation between the occupation and purpose of purchasing gold.

\section{STATEMENT OF PROBLEM}

This study aims to know the reason for consumers buying gold even to available many sort of way to investment money. The investment decision depends upon the availability of money, awareness of diversified investment, influence of the family member. In this study has been made to know consumer investment behavior in gold

\section{SCOPE OF THE STUDY}

This study is an effort to know the customers interest or preference in of knowledge towards investment in gold in Palayamkottai city.

\section{METHODOLOGY}

The primary and secondary data collected for the purpose of the study. I have collected data through questionnaire method. Primary data will be collected in Palayamkottai with the help of set of question. The question is based on objective of the study. Secondary data were collected 
from the published books journals magazines and some reports. In this study chi-square test has been used.

\section{SAMPLE SIZE}

A sample size consists of 100 costumers and respondents were selected from the area in Palayamkottai.

\section{HYPOTHESIS}

$\mathrm{H} 0$; there is no relationship between income and purpose of purchase gold $\mathrm{H} 1$; there is no relationship between occupation and not satisfaction level on wastage

Table 1: Gender of the respondents

\begin{tabular}{|l|l|l|l|}
\hline S. No & Gender & No. of respondents & Percentage \\
\hline 1 & Male & 46 & 46 \\
\hline 2 & Female & 54 & 54 \\
\hline & Total & $\mathbf{1 0 0}$ & $\mathbf{1 0 0}$ \\
\hline
\end{tabular}

The above table shows that $46 \%$ of respondents are male and $54 \%$ of respondents are female.

Table 2: Occupation of the respondents

\begin{tabular}{|l|l|l|l|}
\hline S. No & Occupation & No. of respondents & Percentage \\
\hline 1 & Business Man & 14 & 14 \\
\hline 2 & Professional & 25 & 25 \\
\hline 3 & Govt Employee & 28 & 28 \\
\hline 4 & Private Employee & 33 & 33 \\
\hline & Total & $\mathbf{1 0 0}$ & $\mathbf{1 0 0}$ \\
\hline
\end{tabular}

The above table shows that $33 \%$ of respondents are private employee, $28 \%$ of respondents are government employee, $25 \%$ of respondents are professionals and $14 \%$ of respondents are business man.

Table 3: Income level of the respondents

\begin{tabular}{|l|l|l|l|}
\hline S. No & Income level & No of respondents & Percentage \\
\hline 1 & Up to 15000 & 26 & 26 \\
\hline 2 & $15001-25000$ & 30 & 30 \\
\hline 3 & $25001-35000$ & 21 & 21 \\
\hline 4 & $35001 \&$ above & 23 & 23 \\
\hline & Total & $\mathbf{1 0 0}$ & $\mathbf{1 0 0}$ \\
\hline
\end{tabular}

The above table shows that $30 \%$ of respondents earn 15001-25000, $26 \%$ of respondents earn up to $15000,23 \%$ of respondents earn $35001 \&$ above, $21 \%$ of respondents earn 25001-35000. 
Table 4: Preference of investment in gold and of the respondents

\begin{tabular}{|l|l|l|l|}
\hline S. No & Preference to invest in gold & No. of respondents & Percentage \\
\hline 1 & Liquidity & 26 & 26 \\
\hline 2 & Low risk & 14 & 14 \\
\hline 3 & High return & 21 & 21 \\
\hline 4 & Safe on principle & 39 & 39 \\
\hline & Total & $\mathbf{1 0 0}$ & $\mathbf{1 0 0}$ \\
\hline
\end{tabular}

The above table shows that $39 \%$ respondents are invest in gold for safe on principle, $26 \%$ of respondents are invest in gold for liquidity, $21 \%$ of respondents are invest in gold for high return and $14 \%$ of respondents are invest in low risk

Table 5: Purpose for purchasing of gold of the respondents

\begin{tabular}{|l|l|l|l|}
\hline S. No & Purpose for purchasing of gold & No. of respondents & Percentage \\
\hline 1 & Own use & 46 & 46 \\
\hline 2 & Traditional value & 6 & 6 \\
\hline 3 & Investment purpose & 35 & 35 \\
\hline 4 & Gift to close relatives & 4 & 4 \\
\hline 5 & Status of symbol & 9 & 9 \\
\hline & Total & $\mathbf{1 0 0}$ & $\mathbf{1 0 0}$ \\
\hline
\end{tabular}

The above table shows that $46 \%$ of respondents purchase gold for own use, $35 \%$ of respondents purchase gold for Investment purpose , 9\% of respondents purchase gold for Status of symbol and $6 \%$ of respondents purchase gold for Traditional value and $4 \%$ respondent purchase gold for Gift to close relatives

$\mathrm{H}_{0}$ : there is no significant relationship between occupation and purpose of purchasing gold.

Table 6:

\begin{tabular}{|l|l|l|l|l|l|l|}
\hline $\begin{array}{l}\text { Occupation/ } \\
\text { Purpose of } \\
\text { purchasing } \\
\text { gold }\end{array}$ & $\begin{array}{l}\text { Traditional } \\
\text { value }\end{array}$ & $\begin{array}{l}\text { Investment } \\
\text { purpose }\end{array}$ & $\begin{array}{l}\text { Gift to } \\
\text { close } \\
\text { relatives }\end{array}$ & $\begin{array}{l}\text { Status of } \\
\text { symbol }\end{array}$ & Total \\
\hline $\begin{array}{l}\text { Business } \\
\text { man }\end{array}$ & 5 & 3 & 3 & 1 & 2 & 14 \\
\hline professional & 11 & 2 & 8 & 2 & 2 & 25 \\
\hline $\begin{array}{l}\text { Govt } \\
\text { employee }\end{array}$ & 12 & 3 & 9 & 1 & 3 & 28 \\
\hline $\begin{array}{l}\text { Private } \\
\text { employee }\end{array}$ & 13 & 2 & 13 & 2 & 3 & 33 \\
\hline Total & 41 & 10 & 33 & & & 100 \\
\hline
\end{tabular}

The null hypothesis occupation and purpose of purchasing gold and ornament is independent. 


\begin{tabular}{|c|c|c|c|}
\hline $\mathbf{O}$ & $\mathbf{E}$ & $(\mathrm{O}-\mathrm{E})^{2}$ & $(\mathrm{O}-\mathrm{E})^{2} / 2$ \\
\hline 5 & 5.74 & \begin{tabular}{|l}
0.5476 \\
\end{tabular} & 0.095 \\
\hline 11 & 10.25 & 0.56 & 0.055 \\
\hline 12 & 11.48 & 0.27 & 0.024 \\
\hline \begin{tabular}{|l|}
13 \\
\end{tabular} & 13.53 & 0.28 & \begin{tabular}{|l|}
0.02 \\
\end{tabular} \\
\hline 3 & 1.4 & 2.56 & \begin{tabular}{|l|}
1.83 \\
\end{tabular} \\
\hline 2 & 2.5 & 0.25 & 0.1 \\
\hline 3 & 2.8 & 0.04 & 0.01 \\
\hline 2 & 3.3 & $\begin{array}{l}1.69 \\
\end{array}$ & $\begin{array}{l}0.51 \\
\end{array}$ \\
\hline 3 & 4.62 & 2.624 & \begin{tabular}{|l|}
0.57 \\
\end{tabular} \\
\hline 8 & 8.25 & 0.058 & 0.01 \\
\hline 9 & 9.24 & 0.058 & 0.01 \\
\hline \begin{tabular}{|l|}
13 \\
\end{tabular} & 10.89 & 4.45 & $\begin{array}{l}0.41 \\
\end{array}$ \\
\hline 1 & 0.84 & 0.027 & \begin{tabular}{|l|}
0.03 \\
\end{tabular} \\
\hline 2 & 1.5 & 0.25 & $\begin{array}{l}0.17 \\
\end{array}$ \\
\hline 1 & 1.68 & 0.46 & 0.28 \\
\hline 2 & 1.98 & 0.0004 & $\begin{array}{l}0.00 \\
\end{array}$ \\
\hline 2 & 1.4 & 0.36 & 0.26 \\
\hline 2 & 2.5 & 0.25 & 0.1 \\
\hline 3 & 2.8 & 0.04 & $\begin{array}{l}0.01 \\
\end{array}$ \\
\hline 3 & 3.3 & 0.09 & \begin{tabular}{|l|}
0.03 \\
\end{tabular} \\
\hline & & & 4.524 \\
\hline
\end{tabular}

The table value of $\mathrm{X}^{2}$ for $12 \mathrm{df}$ at $5 \%$ level of significant is 21.026. the calculated value of null hypothesis is less table value so null hypothesis is accepted. Hence the occupation and Purpose of purchasing gold is independent.

Table 7: Reason for not satisfied on wastage of the respondents

\begin{tabular}{|l|l|l|l|}
\hline S. No & Reason for not satisfied on wastage & No. of respondents & Percentage \\
\hline 1 & Arbitrary & 30 & 30 \\
\hline 2 & Vary from design and type & 24 & 24 \\
\hline 3 & Differ from shop to shop & 42 & 42 \\
\hline 4 & Closely related with purity of gold & 4 & 4 \\
\hline & Total & $\mathbf{1 0 0}$ & $\mathbf{1 0 0}$ \\
\hline
\end{tabular}

The above table shows that $42 \%$ of respondents feels that wastage differ from shop to shop, $30 \%$ of respondents feels that wastage arbitrary, $24 \%$ of respondents feels that wastage vary from design and type and $4 \%$ of respondents feels that wastage Closely related with purity of gold .

H1: there is no significant relationship between income and not satisfied on wastage 


\begin{tabular}{|l|l|l|l|}
\hline $\mathbf{O}$ & $\mathbf{E}$ & $(\mathbf{O}-\mathbf{E})^{2}$ & $(\mathbf{O}-\mathbf{E})^{2} / \mathbf{E}$ \\
\hline 7 & 7.80 & 0.64 & 0.103 \\
\hline 6 & 6.24 & 0.06 & 0.01 \\
\hline 13 & 10.92 & 4.33 & 0.396 \\
\hline 0 & 1.04 & 1.08 & 1.04 \\
\hline 9 & 9.00 & 0 & 0 \\
\hline 8 & 7.24 & 0.58 & 0.0797 \\
\hline 12 & 12.6 & 0.36 & 0.03 \\
\hline 1 & 1.2 & 0.04 & 0.03 \\
\hline 6 & 6.3 & 0.09 & 0.014 \\
\hline 6 & 5.04 & 0.92 & 0.18 \\
\hline 8 & 8.82 & 0.67 & 0.076 \\
\hline 1 & 0.82 & 0.03 & 0.039 \\
\hline 8 & 6.9 & 8.41 & 1.28 \\
\hline 4 & 5.52 & 2.31 & 0.42 \\
\hline 9 & 9.66 & 0.44 & 0.05 \\
\hline 2 & 0.92 & 1.17 & 1.24 \\
\hline & & Total & $\mathbf{4 . 9 3}$ \\
\hline$X^{2}-2\left(0-\mathbf{n}^{2}\right.$ & & & \\
\hline
\end{tabular}

$\mathrm{X}^{2}=\sum(\mathrm{O}-\mathrm{E})^{2} / \mathrm{E}$

$\mathrm{V}=(\mathrm{r}-1)(\mathrm{c}-1)=(4-1)(4-1)$

$=3 \times 3$

$\mathrm{V}=9$

The table value of $\mathrm{X}^{2}$ for $9 \mathrm{df}$ at $5 \%$ level of significant is 16.919 the calculated value of null hypothesis is less table value so null hypothesis is accepted. Hence the income and not satisfied on wastage is independent.

Table 8: Opinion of respondents varies gold investment scheme in jewelry shop

\begin{tabular}{|l|l|l|l|}
\hline S. No & $\begin{array}{l}\text { Opinion about varies investment schemes in jewelry } \\
\text { shop }\end{array}$ & $\begin{array}{l}\text { No. of } \\
\text { respondents }\end{array}$ & Percentage \\
\hline 1 & Stimulate habit of investment & 40 & 40 \\
\hline 2 & Kind of cheating & 34 & 34 \\
\hline 3 & Help middle class people to make invest & 26 & 26 \\
\hline & Total & $\mathbf{1 0 0}$ & $\mathbf{1 0 0}$ \\
\hline
\end{tabular}

The above table shows that $40 \%$ of respondents think investment scheme stimulate habit of investment, 34\% of respondents think investment scheme is a kind of cheating, $26 \%$ of respondents think investment scheme help middle class people to make invest.

\section{FINDINGS}

- In this research article says $54 \%$ of female respondents invest in gold mostly.

- The research study says that 30\% of respondents invest in gold come under 15001-25000 level.

- The study shows that $39 \%$ of respondents thinks that invest in gold is safe on principle. 
- In this research finding $46 \%$ of respondents buy gold for their own use.

- In this research finding says that $42 \%$ of respondents are not satisfied on wastage because it differ from shop to shop.

- $40 \%$ respondent thinks that investment scheme stimulate the habit of investment, next majority people says that it's a kind of cheating.

\section{SUGGESTION}

- Double income is getting in home due to growth of number of working women. There should be made catching advertisement to provide right information and knowledge about investment market.

- Investor should take help of financial advisor to know about various investment options in gold like bond, share.

\section{CONCLUSION}

Buyer's investment behavior changes depending up on their age, gender, income, occupation and their expectation level on return. In this article majority of respondent female s, they are very willing given the answer to this gold investment article. There is no big difference between the investment behaviors in gold among working people in different job. Not only people keen to invest their money in gold, they think it's safe on principle. Majority of working people prefer to buy gold for their own use. There is no relationship between occupation and purpose of purchasing gold among respondents. People Income level and their satisfaction level on wastage has no relationship. Almost all level of income group not satisfied on wastage they charged on gold. Majority of people think various gold investment scheme stimulate the habit among people. Thus the investment behavior on gold don't change even the multiple option of investment is avail.

\section{REFERENCE}

[1] Golden, S. A. R., \& Regi, S. B. (2015). Satisfaction of Customers towards User Friendly Technological Services offered by Public and Private Sector banks at Palayamkottai, Tirunelveli

[2] Marketing management, Dr.karunakaran, 2010,page no. 55-76

[3] Marketing management, Philip kotler, Kevin lane keller, A baham koshy, mithileshwar jha, 2012, page no 106-128

[4] Marketing, grewal levy, Pearson publication, 2008, page no. 123.

[5] Regi, S. B. \& S, A. R. G. (2014). "A DESCRIPTIVE STUDY ON THE ROLE OF CONSUMER

PSYCHOLOGY AND BEHAVIOUR IN PRODUCT PURCHASING”. Indian Streams Research Journal, 3. 